\title{
ANALISIS HUBUNGAN JENIS DAN FREKUENSI MENGKONSUMSI JAJANAN KARIOGENIK DENGAN KEJADIAN RAMPAN KARIES PADA ANAK USIA 5-6 TAHUN DI KOTA PADANG
}

\author{
(ANALYSIS OF RELATIONSHIPS THE TYPE AND FREQUENCY TO CONSUME \\ CARIOGENIC SNACK ON CARIES RAMPAN INCIDENCE IN CHILDREN AGE 5-6 \\ YEARS IN PADANG)
}

\author{
Febrian $^{1}$, Rosfita Rasyid ${ }^{2}$, Ditha Noviantika ${ }^{3}$
}

\begin{abstract}
Abstrak
Karies merupakan masalah utama kesehatan gigi dan mulut. Karies sering ditemukan pada anak-anak adalah karies susu botol dan karies Rampan. Mengkonsumsi makanan kariogenik merupakan penyebab terjadinya karies rampan. Penelitian ini bertujuan untuk mengetahui hubungan jenis dan frekuensi mengkonsumsi makanan kariogenik dengan kasus karies rampan yang terjadi pada anak usia 5-6 tahun. Rancangan penelitian yang digunakan adalah analitik observasional dengan metode cross sectional, teknik pengambilan sampling secara purposive dengan jumlah sampel menggunakan total sampling, analisa uji statistik menggunakan chi square. Subjek penelitian adalah anak usia pra-sekolah dari 3 Unit Pra-sekolah yang ada di Padang. Terdapat hubungan yang signifikan antara jenis konsumsi makanan kariogenik dengan karies rampan ( $p=0,005)$, ada hubungan yang signifikan antara frekuensi konsumsi makanan ringan kariogenik dengan karies rampan $(p=0,000)$. Disarankan kepada orang tua untuk mengontrol dan memantau jenis dan frekuensi konsumsi makanan kariogenik pada anak-anak.
\end{abstract}

Kata kunci: Karies rampan, jenis dan frekuensi konsumsi makanan kariogenik, anak-anak usia 5-6 tahun

\section{Abstract}

Caries is the main problem of oral health. Caries are frequently found in children are milk bottle caries and caries Rampan. Cariogenic food consumption is a Rampant caries etiology. This study was to determine the relationship of type and frequency to consume cariogenic snacks with the case of caries Rampant in children age 5 -6 years. The research method used is analytic observational study design with a cross sectional study, samples were taken purposive methode with total sampling technique and using the chisquare statistical test. Subjects were pre-school age children from 3 unit Pre-school in Padang.There is a significant relationship between the type of consumption of cariogenic snacks with caries Rampant $(p=0,005)$, There is a significant relationship between frequency of consumption of cariogenic snacks with caries Rampant $(p=0,000)$.It is suggested to parents to control and monitor the type and frequency of consumption of cariogenic snacks in children.

Key words : Caries Rampant; the type and frequency of consumption of cariogenic snacks; children age 5-6 years

\footnotetext{
${ }^{1}$ Staf Pengajar Fakultas Kedokteran Gigi Universitas Andalas

${ }^{2}$ Staf Pengajar Fakultas Kedokteran Universitas Andalas

${ }^{3}$ Mahasiswa Fakultas Kedokteran Universitas Andalas
} 


\section{PENDAHULUAN}

Kesehatan gigi dan mulut merupakan bagian dari kesehatan tubuh yang tidak dapat dipisahkan satu dan lainnya karena akan mempengaruhi kesehatan tubuh keseluruhan. ${ }^{1,2}$ Penyakit gigi dan mulut merupakan penyakit tertinggi keenam yang dikeluhkan masyarakat Indonesia (Survei Kesehatan Rumah Tangga). Prevalensi nasional masalah gigi-mulut adalah $23,5 \%$ sedangkan prevalensi karies aktif adalah 43,4\%.Prevalensi penduduk Sumatera Barat yang mempunyai masalah kesehatan gigi dan mulut menurut Laporan Riset Kesehatan Dasar adalah 21,6 \%. Penyakit gigi dan mulut merupakan penyakit dengan peringkat pertama diantara sepuluh penyakit terbanyak di Kota Padang. Hal ini ditunjukkan dengan jumlah penyakit gigi yang ditemui pada anak sekolah TK Kota Padang tahun 2009 sebesar 52\%., 4 Menurut Laporan Dinas Kesehatan Kota Padang, dari 10 puskesmas yang melakukan pemeriksaan gigi dan mulut pada anak TK, prevalensi karies tertinggi berasal dari TK di wilayah kerja Puskesmas Andalas sebesar 46,57\%. ${ }^{5}$

Prevalensi karies gigi sulung lebih tinggi dibandingkan dengan gigi tetap.Hal ini disebabkan proses kerusakannya kronis dan asimptomatis, struktur email gigi sulung yang kurang padat karena banyak mengandung air, dan pola diet kariogenik yang tidak seimbang.Frekuensi karies pada gigi sulung merupakan indikator kesehatan gigi anak usia prasekolah yang diperlukan untuk menilai keadaan kesehatan gigi sekaligus keberhasilan upaya kesehatan gigi usia prasekolah dan usia balita. $^{1,6}$

Karies yang sering dijumpai pada anak-anak adalah karies susu botol (nursing bottle caries) dan karies rampan. menyatakan bahwa rampan karies sebagai karies yang datang tiba tiba dalam waktu yang cepat dan mengenai hampir sebagian besar gigi baik rahang atas maupun rahang bawah pada anak anak dan remaja ${ }^{7}$. Tahap awal terjadinya rampan karies secara klinis berupa terbentuknya dekalsifikasi email gigi yang berwarna putih dan kemudian berubah menjadi coklat atau kehitaman secara cepat yang mengenai seluruh permukaan email gigi ${ }^{7}$. Gambaran khas dari rampan karies adalah terlibatnya gigi yang imun karies yaitu gigi insisivus depan bawah dengan terkenanya daerah proksimal gigi insisivus bawah yang dapat berkembang mengenai daerah servikal oleh karena itu Massler, mendefinisikan bahwa rampant caries adalah lesi karies yang timbul secara cepat, destruktif dan meyebar secara luas 
hingga mengenai seluruh gigi termasuk pada gigi yang pada umumnya selalu dipandang imun terhadap karies. ${ }^{8}$ Karies rampan merupakan penyakit yang berhubungan dengan banyak faktor (multiple factor) yang merupakan hasil dari keterlibatan dari host, bakteri, substrat, dan waktu. Selain itu, etiologi karies rampan dihubungkan dengan berbagai faktor resiko. Biasanya diakibatkan karena pemberian makanan yang bersifat kariogenik tidak terkontrol karena anak menyukai makanan manis dan belum bisa menjaga kebersihan rongga mulutnya dengan baik sehingga masih membutuhkan orang lain. ${ }^{9}$

Pada umumnya hampir semua anak menyukai jajanan yang rasanya manis seperti coklat, permen, es krim, biskuit, cake, permen karet, dan minuman ringantermasuk minuman berkarbonasi dan snacks lain yang tinggi kandungan sukrosanya diantara jam makan. Jenis makanan ini merupakan karbohidrat yang sangat kariogenik dan berpotensi mengakibatkan karies.Para ahli sependapat bahwa karbohidrat yang berhubungan dengan proses karies adalah polisakrida, disakarida, monosakarida, dan sukrosa yang mempunyai kemampuan yang lebih efisien terhadap pertumbuhan mikroorganisme asidogenik dibandingkan karbohidrat lain. ${ }^{10}$
Penelitian Holbrook dkk, di Iceland menyatakan pada usia 5 tahun ditemukan hubungan antara frekuensi mengonsumsi gula terhadap perkembangan karies pada anak. Berdasarkan hasil penelitiannya diketahui bahwa anak yang mengonsumsi makanan atau minuman bergula empat kali per hari atau lebih atau anak yang makan jajan tiga kali per hari atau lebih menyebabkan skor karies meningkat. ${ }^{10}$

Berdasarkan uraian-uraian di atas penulis tertarik untuk melakukan kajian hubungan jenis jajanan dan frekuensi mengonsumsi jajanan kariogenik dengan kejadian karies rampan pada anak usia 56 tahun. Tempat penelitian yang dipilih adalah 3 TK yaitu TK Aisyiah XXXI, TK M.Nur, dan TK Nurul Amin karena sekolah tersebut memiliki prevalensi karies tertinggi di antara TK lainnya di wilayah kerja puskesmas Andalas.

\section{MATERI DAN METODE}

Kajian dalam penelitian ini adalah perilaku yang mencakup hubungan jenis jajanan dan frekuensi konsumsi jajanan kariogenik dengan kejadian karies rampan. Kajian ini menggunakan rancangan penelitian analitik observasional dengan metode cross sectional. Teknik pengambilan sampel dilakukan metode purposive sampling dengan jumlah sampel menggunakan total sampling 


\section{Data Primer}

Jenis data primer yang dikumpulkan adalah :

\section{a. Jenis jajanan dan frekuensi}

\section{konsumsi jajanan kariogenik}

Data yang diperoleh di lapangan dengan cara wawancara langsung kepada orangtua (ibu) menggunakan kuesioner yang dibuat dan disesuaikan dengan kebutuhan data untuk penelitian, yaitu tentang jenis jajanan dan frekuensi konsumsi jajanan kariogenik.

\section{b. Kejadian karies rampan}

Data kejadian karies rampan diperoleh dengan melakukan pemeriksaan gigi kepada anak di TK Aisyiah XXXI, TK M.Nur, dan TK Nurul Amin

\section{Data Sekunder}

Data sekunder diperoleh dari pencatatan jumlah populasi anak TK di wilayah kerja Puskesmas Andalas.

\section{Analisa Data}

1. Analisa Univariat

Analisa univariat dilakukan untuk melihat distribusi frekuensi dari masing-masing variabel independen (jenis jajanan dan frekuensi mengonsumsi jajanan kariogenik) dan variabel dependen (kejadian karies rampan), serta distribusi umur dan jenis kelamin. Data disajikan secara deskriptif dan disajikan dalam bentuk tabel distribusi frekuensi.

2. Analisa Bivariat

Untuk melihat hubungan dua variabel yaitu variabel jenis jajanan dan frekuensi mengonsumsi jajanan dengan kejadian karies rampan menggunakan uji statistik Chi-square. Uji ini dilakukan karena variabel dependen dan independen merupakan variabel kategotik. Nilai yang digunakan untuk melihat ada tidaknya hubungan dua variabel adalah nilai $p$, bila $\mathrm{p}<0,05$ berarti terdapat hubungan bermakna.

\section{HASIL PENELITIAN}

\section{Karakteristik Responden}

Grafik 1 Distribusi berdasarkan jenis kelamin

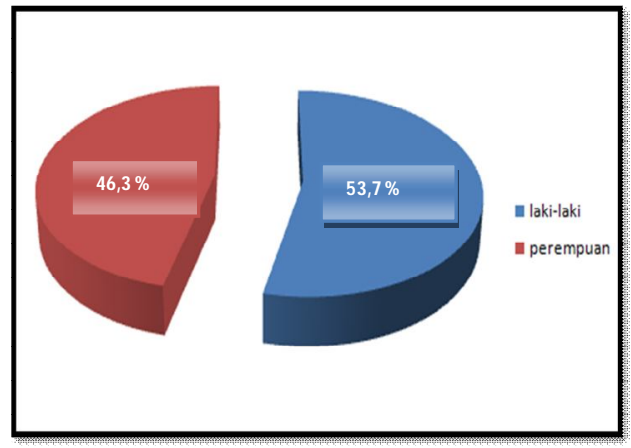

Berdasarkan Grafik 1 diketahui bahwa distribusi responden berjenis kelamin laki-laki lebih banyak daripada responden 
berjenis kelamin perempuan yaitu $53,7 \%$.

Grafik 2 Distribusi berdasarkan usia

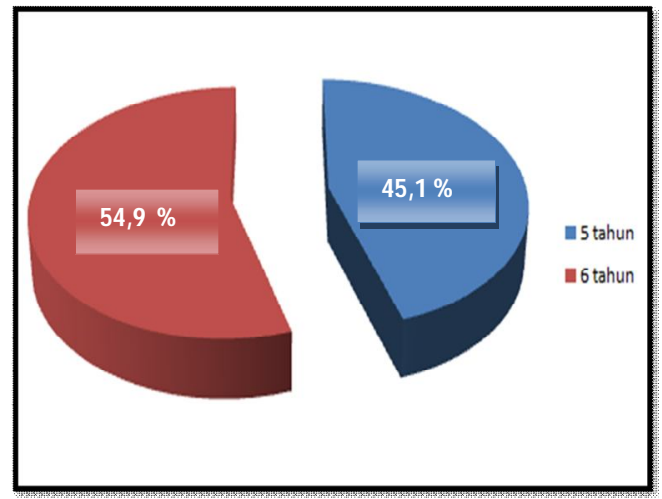

Berdasarkan Grafik 2 diketahui bahwa distribusi responden dengan usia 6 tahun lebih banyak daripada responden usia 5 tahun yaitu $54,9 \%$.

\section{Hasil Pemeriksaan}

Grafik 1 Distribusi berdasarkan kejadian karies rampan

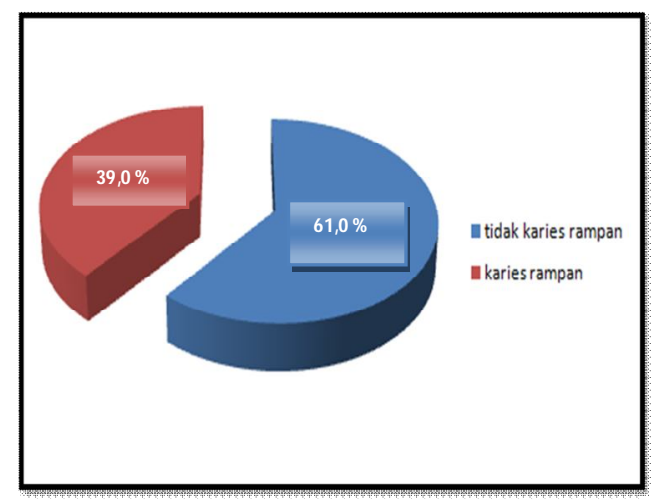

Berdasarkan Grafik 1 diketahui bahwa jumlah responden yang menderita karies rampan lebih sedikit dibandingkan yang tidak menderita karies rampan, yaitu $39,0 \%$.

\section{Jenis Jajanan Kariogenik}

Grafik 1 Distribusi jenis jajanan kariogenik

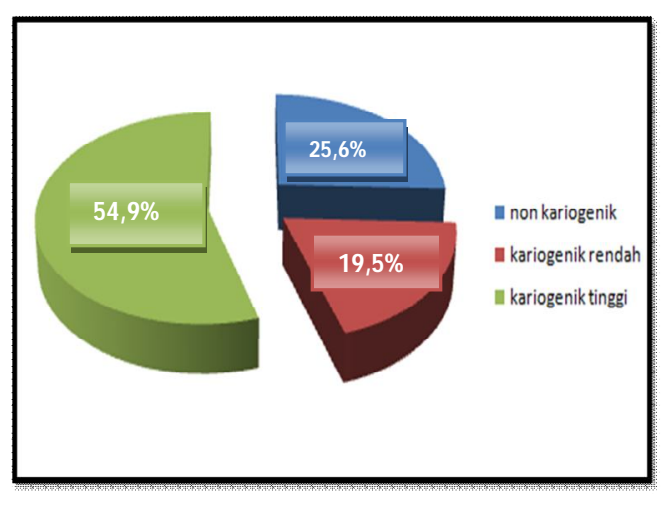

Berdasarkan Grafik 1 diketahui bahwa distribusi jenis jajanan yang paling banyak dikonsumsi oleh responden adalah jenis jajanan kariogenik tinggi yaitu $54,9 \%$.

\section{Frekuensi Konsumsi Jajanan Kariogenik}

Grafik 1 Distribusi frekuensi konsumsi jajanan kariogenik

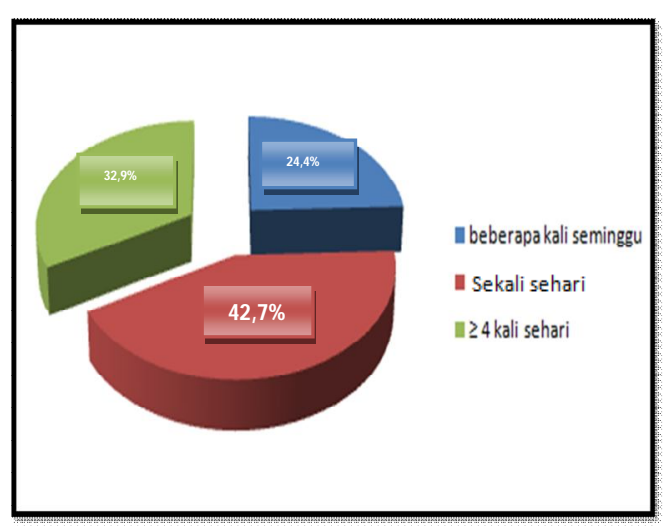


Berdasarkan Grafik 1 diketahui bahwa frekuensi konsumsi jajanan kariogenik yang paling banyak responden pilih adalah sekali sehari yaitu $42,7 \%$.

\section{Hubungan Jenis Jajanan Kariogenik} dengan Kejadian Karies Rampan

Tabel 1 Hubungan Jenis Jajanan Kariogenik dengan Kejadian Karies Rampan

\begin{tabular}{|c|c|c|c|c|c|c|c|}
\hline \multirow{3}{*}{$\begin{array}{c}\text { Jenis } \\
\text { Jajanan } \\
\text { Kariogenik }\end{array}$} & \multicolumn{4}{|c|}{ Kejadian Karies Rampan } & \multirow{2}{*}{\multicolumn{2}{|c|}{ Total }} & \multirow{3}{*}{ PValue } \\
\hline & \multicolumn{2}{|c|}{$\begin{array}{c}\text { Tidak Karies } \\
\text { Rampan }\end{array}$} & \multicolumn{2}{|c|}{$\begin{array}{c}\text { Karies } \\
\text { Rampan }\end{array}$} & & & \\
\hline & $\mathrm{F}$ & $\%$ & $\mathrm{f}$ & $\%$ & f & $\%$ & \\
\hline Non & 19 & 90,5 & 2 & 9,5 & 21 & 100 & \\
\hline Kariogenik & & & & & & & \\
\hline Kariogenik & 7 & 43,8 & 9 & 56,3 & 16 & 100 & \\
\hline Rendah & & & & & & & 0,005 \\
\hline $\begin{array}{l}\text { Kariogenik } \\
\text { Tinggi }\end{array}$ & 24 & 53,3 & 21 & 46,7 & 45 & 100 & \\
\hline Total & 50 & 61,0 & 32 & 39,0 & 82 & 100 & \\
\hline
\end{tabular}

Berdasarkan Tabel 1 diketahui bahwa responden yang paling banyak menderita karies rampan adalah responden yang mengonsumsi jajanan kariogenik rendah yaitu $56,3 \%$. Dari hasil analisa statistik dengan menggunakan uji Chi Square diperoleh $\mathrm{p}=0,005(p<0,05)$, yang artinya ada hubungan yang bermakna antara mengonsumsi jenis jajanan kariogenik dengan kejadian karies rampan.

Hubungan Frekuensi Mengonsumsi Jajanan Kariogenik dengan Kejadian Karies Rampan
Tabel 1 Hubungan Frekuensi Mengonsumsi Jajanan Kariogenik dengan Kejadian Karies Rampan

\begin{tabular}{|c|c|c|c|c|c|c|c|}
\hline \multirow{3}{*}{$\begin{array}{c}\text { Frekuensi } \\
\text { Mengonsumsi } \\
\text { Jajanan } \\
\text { Kariogenik }\end{array}$} & \multicolumn{4}{|c|}{ Kejadian Karies Rampan } & \multirow{2}{*}{\multicolumn{2}{|c|}{ Total }} & \multirow{3}{*}{ PValue } \\
\hline & \multicolumn{2}{|c|}{$\begin{array}{c}\text { Tidak Karies } \\
\text { Rampan }\end{array}$} & \multicolumn{2}{|c|}{$\begin{array}{c}\text { Karies } \\
\text { Rampan }\end{array}$} & & & \\
\hline & f & $\%$ & $F$ & $\%$ & $\mathrm{f}$ & $\%$ & \\
\hline Beberapa Kali & 18 & 90,0 & 2 & 10,0 & 20 & 100 & \\
\hline \multicolumn{8}{|l|}{ Seminggu } \\
\hline Setiap hari & 24 & 68,6 & 11 & 31,4 & 35 & 100 & 0,000 \\
\hline$\geq 4$ Kali Sehari & 8 & 29,6 & 19 & 70,4 & 27 & 100 & \\
\hline Total & 50 & 61,0 & 32 & 39,0 & 82 & 100 & \\
\hline
\end{tabular}

Berdasarkan Tabel 1 diketahui bahwa responden yang paling banyak menderita karies rampan adalah responden yang mengonsumsi jajanan kariogenik dengan frekuensi $\geq 4$ kali sehari yaitu $70,4 \%$. Dari hasil analisa statistik dengan menggunakan uji Chi Square diperoleh $\mathrm{p}=0,000 \quad(p<0,05), \quad$ yang artinya ada hubungan yang bermakna antara frekuensi mengonsumsi jajanan kariogenik dengan kejadian karies rampan.

Hubungan Jenis Kelamin dengan Kejadian Karies Rampan

Tabel 1 Hubungan Jenis Kelamin dengan Kejadian Karies Rampan 


\begin{tabular}{|c|c|c|c|c|c|c|c|}
\hline \multirow{3}{*}{$\begin{array}{c}\text { Jenis } \\
\text { Kelamin }\end{array}$} & \multicolumn{4}{|c|}{ Kejadian Karies Rampan } & \multirow{2}{*}{\multicolumn{2}{|c|}{ Total }} & \multirow{3}{*}{ PValue } \\
\hline & \multicolumn{2}{|c|}{$\begin{array}{c}\text { Tidak Karies } \\
\text { Rampan }\end{array}$} & \multicolumn{2}{|c|}{$\begin{array}{l}\text { Karies } \\
\text { Rampan }\end{array}$} & & & \\
\hline & $\mathrm{f}$ & $\%$ & $f$ & $\%$ & 1 & $\%$ & \\
\hline Laki-laki & 22 & 50,0 & 22 & 50,0 & 44 & 100 & \\
\hline Perempuan & 28 & 73,7 & 10 & 26,3 & 38 & 100 & 0,049 \\
\hline Total & 50 & 61,0 & 32 & 39,0 & 82 & 100 & \\
\hline
\end{tabular}

Berdasarkan Tabel 1 diketahui bahwa responden yang paling banyak menderita karies rampan adalah laki-laki yaitu 50\%. Dari hasil analisa statistik dengan menggunakan uji Chi Square diperoleh $\mathrm{p}=0,049 \quad(p<0,05), \quad$ yang artinya ada hubungan yang bermakna antara jenis kelamin dengan kejadian karies rampan.

\section{Hubungan Usia dengan Kejadian Karies Rampan}

Tabel 1 Hubungan Usia dengan Kejadian Karies Rampan

\begin{tabular}{|c|c|c|c|c|c|c|c|}
\hline \multirow{3}{*}{$\begin{array}{c}\text { Usia } \\
\text { (Tahun) }\end{array}$} & \multicolumn{4}{|c|}{ Kejadian Karies Rampan } & \multirow{2}{*}{\multicolumn{2}{|c|}{ Total }} & \\
\hline & \multicolumn{2}{|c|}{$\begin{array}{c}\text { Tidak Karies } \\
\text { Rampan }\end{array}$} & \multicolumn{2}{|c|}{$\begin{array}{l}\text { Karies } \\
\text { Rampan }\end{array}$} & & & $P V_{3}$ \\
\hline & $\mathrm{f}$ & $\%$ & $\mathrm{f}$ & $\%$ & $f$ & $\%$ & \\
\hline 5 & 25 & 67,6 & 12 & 32,4 & 37 & 100 & \\
\hline 6 & 25 & 55,6 & 20 & 44,4 & 45 & 100 & 0,378 \\
\hline Total & 50 & 1,0 & 32 & 39,2 & 82 & 100 & \\
\hline
\end{tabular}

Berdasarkan Tabel 1 diketahui bahwa responden yang paling banyak menderita karies rampan adalah usia 6 tahun yaitu 44,4\%. Dari hasil analisa statistik dengan menggunakan uji Chi Square diperoleh $\mathrm{p}=0,378(p<0,05)$, yang artinya tidak ada hubungan yang bermakna antara usia dengan kejadian karies rampan.

\section{PEMBAHASAN}

\section{Hubungan Jenis Jajanan Kariogenik dengan Kejadian Karies Rampan}

Hasil uji statistik menunjukkan $\mathrm{P}$ value $=0,005(\mathrm{P}<0,05)$, yang berarti ada hubungan bermakna antara jenis jajanan kariogenik dengan kejadian karies rampan. Secara umum, dari hasil penelitian terlihat bahwa anak lebih memilih jajanan kariogenik tinggi yaitu $54,9 \%$. Mereka menyukai jajanan yang bersifat manis, lunak, dan lengket seperti coklat, permen, roti, donat, es krim, dan minuman ringan. Hal ini mungkin disebabkan karena jenis jajanan seperti ini banyak dijual di sekitar sekolah ataupun di sekitar lingkungan rumah dengan harga terjangkau, kemasan menarik, serta dapat memberi rasa enak dan kenyang sehingga disukai anak-anak. Menurut penelitian Lilik Hidayati lebih dari setengah anak-anak dalam penelitiannya memiliki tingkat kesukaan terhadap makanan kariogenik tinggi yaitu $71,6 \%$. Hal ini sesuai dengan penelitian Kornekiani yang menyatakan bahwa sebagian besar anak yaitu 81,7\% memiliki tingkat kesukaan terhadap makanan kariogenik tinggi. Rasa manis merupakan kualitas kecapan yang 
disenangi manusia sejak lahir. Apabila anak diberi pilihan dari berbagai rasa (manis, pahit, asin, dan asam), maka rasa manis akan selalu menjadi pilihan utama. $^{11}$

Berdasarkan hasil penelitian diketahui bahwa responden yang memilih jajanan non kariogenik menderita karies rampan sebanyak 9,5\%. Hal ini disebabkan karena adanya faktor lain penyebab karies rampan selain makanan kariogenik seperti struktur gigi yang kurang baik, faktor psikologis, kebersihan mulut yang buruk, serta faktor pemeliharaan kesehatan gigi. Berdasarkan hasil penelitian, responden yang paling banyak menderita karies rampan adalah responden yang mengonsumsi jajanan kariogenik rendah yaitu 56,3\%. Jenis jajanan kariogenik rendah adalah susu, buah-buahan, dan produk olahan gandum. Jenis gula yang ditemukan pada buah-buahan adala fruktosa. Rasanya 1,7 lebih manis dari sukrosa. Rantai susunan kimia fruktosa mudah dipecah menjadi asam oleh bakteri dalam plak, sehingga tidak baik untuk gigi jika digunakan sebagai pemanis tambahan. Akan tetapi, buah-buahan dapat menguntungkan bagi gigi karena cara mengonsumsi buahbuahan biasanya dalam bentuk potongan yang cepat ditelan dan bersifat merangsang air liur. Sedangkan jenis makanan kariogenik rendah lainnya adalah produk gandum, diketahui gandum memiliki unsur karbohidrat, sedikit glukosa, sedikit protein tapi kaya akan mineral, vitamin, dan kalsium. ${ }^{12}$ Secara umum, dari hasil penelitian terlihat bahwa jajanan kariogenik rendah yang paling banyak dikonsumsi responden adalah susu. Hampir seluruh responden yang mengonsumsi kariogenik rendah yang menderita karies rampan mempunyai riwayat mengonsumsi susu botol. Gula yang terdapat dalam susu merupakan jenis laktosa, yaitu gabungan gabungan dari dua jenis gula sederhana yaitu glukosa dan galaktosa. ${ }^{12}$ Menurut Boedihardjo, gula yang berada dalam susu nantinya akan diubah menjadi asam oleh bakteri yang kemudian asam tersebut akan melarutkan email gigi. Laktosa yang terkandung dalam susu akan diubah oleh mikroorganisme menjadi asam laktat dengan $\mathrm{pH}$ 5,5. Ini merupakan $\mathrm{pH}$ kritis yang dapat mempercepat timbulnya lubang pada gigi. ${ }^{1}$ Hal ini juga didukung oleh pendapat Heriadi Sutadi, faktor yang paling sering ditemukan dan sangat erat kaitannya dengan karies rampan yaitu adanyakebiasaan mengisap susu botol terutama menjelang tidur malam. Pada saat itu susu yang menggenang di dalam mulut selain merupakan media 
pertumbuhan bakteri karena mengandung sukrosa juga mengandung laktosa sehingga terjadi demineralisasi email gigi yang lebih cepat. ${ }^{13}$ Selain disebabkan karena riwayat konsumsi susu botol, tingginya kejadian karies rampan pada anak yang mengonsumsi jajanan kariogenik rendah juga disebabkan oleh faktor pemeliharaan kebersihan gigi. Walaupun pemeliharaan kesehatan gigi baik tetapi tidak dilakukan pada waktu yang tepat.Waktu menggosok gigi yang sebaiknya dipilih adalah setelah makan pagi dan sebelum tidur. Pemilihan waktu ini disebabkan karena pada saat-saat itu efek self cleansing alamiah tidak dalam keadaan aktif. Namun, sebagian besar anak menggosok gigi pada pagi dan sore hari pada saat mandi dengan alasan kepraktisan.

Berdasarkan hasil penelitian, anakanak dengan jenis jajanan kariogenik tinggi seperti permen, coklat, donat, dll menderita karies rampan sebanyak $46,7 \%$. Semua variasi dari coklat dan permen hampir $100 \%$ adalah sukrosa. Sukrosa merupakan gabungan dari dua macam gula yaitu glukosa dan fruktosa. Sukrosa dianggap lebih berbahaya dari gula lainnya karena mampu memproduksi lebih banyak perekat glukan untuk membuat plak dalam mulut semakin tebal dan lengket. ${ }^{12}$ Sukrosa dikatalisis oleh GTase S.mutans menjadi glukan ekstraseluler yang tidak larut dalam air dan lengket. Di dalam sel kuman yang berkolonisasi di dalam plak gigi, sakar diet akan dimetabolisme melalui jalur glikolisis anaerob untuk mendapatkan energi. Melalui jalur ini S.mutans akan membentuk asam laktat sebagai satu-satunya produk akhir yang dapat mendemineralisasi email.Selain itu, menurut Carol Drinkard dkk, sukrosa merupakan disakarida khusus yang mempunyai energi tinggi dari proses hidrolisis dan memproduksi dextran dalam jumlah besar yang menjadi bagian utama dari plak karena itulah sukrosa disebut sebagai gula plaing kariogenik. ${ }^{14}$

Menurut GB Winter dkk, sukrosa kemungkinan adalah penyebab utama karies rampan yang terjadi pada gigi sulung. Hal ini diperkuat oleh penelitian yang dilakukan Elianora, yang menyebutkan bahwa salah satu etiologi penyebab karies rampan adalah pemberian makanan bersifat kariogenik yang tidak terkontrol sedangkan anak belum bisa menjaga kebersihan rongga mulutnya dengan baik. ${ }^{9,15}$

\section{Hubungan Frekuensi Mengonsumsi} Jajanan Kariogenik dengan Kejadian Karies Rampan 
Hasil uji statistik menunjukkan $P$ value $=0,000(\mathrm{P}<0,05)$, yang berarti ada hubungan bermakna antara frekuensi mengonsumsi jajanan kariogenik dengan kejadian karies rampan pada anak TK. Frekuensi mengonsumsi jajanan kariogenik adalah berapa kali subjek makan makanan manis yang dapat menyebabkan karies di luar jam makan utama seperti makan pagi, makan siang, dan makan malam. Menurut Stephen dan Joya dalam penelitiannya bahwa semakin sering individu mengonsumsi makanan yang mengandung karbohidrat dan gula di antara jam makan dapat menyebabkan karies rampan. ${ }^{16}$

Berdasarkan hasil penelitian, responden yang mengonsumsi jajanan kariogenik $\geq$ empat kali sehari yang menderita karies rampan adalah 70,4\%, lebih banyak dibandingkan dengan responden yang mengonsumsi jajanan kariogenik sekali sehari. Menurut King Bugers, apabila makanan manis dikonsumsi beberapa kali dalam sehari maka gigi akan berada pada suasana asam terus menerus sehingga dapat merusak gigi sepanjang hari. Hal ini sesuai dengan penelitian Gustafsson dan Lundvist menyatakan bahwa prevalensi karies berhubungan langsung dengan frekuensi makan makanan yang mengandung gula diantara waktu atau 'ngemil' dan terbukti bahwa frekuensi 'ngemil', khususnya jika jenis makanan yang dimakan di antara waktu makan tersebut mengandung gula yang mudah melekat pada gigi, akan meningkatkan kejadian karies gigi. ${ }^{17,18}$

Menurut Food and Drug Administration, frekuensi konsumsi makanan kariogenik sangat berkontribusi dalam kejadian karies gigi dan masalah lainnya. Hal ini disebabkan karena makanan dan minuman yang mengandung gula akan menurunkan $\mathrm{pH}$ plak dengan cepat sampai pada level yang dapat menyebabkan demineralisasi email. Plak akan tetap bersifat asam selama beberapa waktu. Untuk kembali ke $\mathrm{pH}$ normal sekitar 7, dibutuhkan waktu 30-60 menit. Oleh karena itu, konsumsi gula yang sering dan berulangulang akan tetap menahan $\mathrm{pH}$ plak di bawah normal dan menyebabkan demineralisasi email. ${ }^{19}$

\section{Hubungan Jenis Kelamin dengan Kejadian Karies Rampan}

Hasil uji statistik menunjukkan $\mathrm{P}$ value $=0,049(\mathrm{P}<0,05)$, yang berarti ada hubungan bermakna antara jenis kelamin dengan kejadian karies rampan pada anak TK. Responden yang terkena karies rampan sebanyak 32 anak dari jumlah tersebut responden laki-laki menderita 
karies rampan paling banyak yaitu 22 orang. Prevalensi karies rampan pada anak laki-laki lebih tinggi daripada anak perempuan, hal ini disebabkan karena anak laki-laki cendrung sulit diajak bekerjasama dalam pemeliharaan kesehatan gigi. Hasil penelitian ini tidak sejalan dengan penelitian Meishi yang menyimpulkan bahwa tidak ada hubungan yang bermakna antara jenis kelamin dengan timbulnya karies gigi. ${ }^{20}$

Hasil penelitian ini juga berbeda dengan penelitian Furi Andanawari yang menyatakan bahwa prevalensi karies gigi pada kelompok perempuan sedikit lebih tinggi daripada kelompok anak laki-laki. Hal ini seseuai dengan pendapat Tarigan yang menyatakan prevalensi karies gigi sulung anak perempuan sedikit lebih tinggi daripada anak laki-laki. Erupsi gigi anak perempuan lebih cepat dibandingkan anak laki-laki sehingga gigi anak permpuan lebih lama di dalam mulut. Akibatnya gigi anak perempuan akan lebih lama berhubungan dengan faktor resiko terjadinya karies. ${ }^{21}$

\section{Hubungan Usia dengan Kejadian Karies Rampan}

Hasil uji statistik menunjukkan $\mathrm{P}$ value $=0,378 \quad(\mathrm{P}<0,05)$, yang berarti tidak ada hubungan bermakna antara usia dengan kejadian karies rampan pada anak
TK. Dari hasil penelitian diketahui bahwa anak usia 6 tahun yang menderita karies rampan sebanyak 44,4\% lebih banyak dibandingkan usia 5 tahun sebanyak $32,4 \%$. Hal ini tidak sejalan dengan pendapat Furi Andanawari yang menyatakan bahwa prevalensi karies meningkat sesuai dengan pertambahan usia.

\section{KESIMPULAN}

1. Prevalensi karies rampan di $3 \mathrm{TK}$ di kota padang adalah $39 \%$.

2. Ada hubungan yang bermakna antara konsumsi jenis jajanan kariogenik dengan kejadian karies rampan pada anak TK

3. Ada hubungan yang bermakna antara frekuensi konsumsi jajanan kariogenik dengan kejadian karies rampan pada anak TK

4. Ada hubungan yang bermakna antara jenis kelamin dengan kejadian karies rampan pada anak TK

5. Tidak ada hubungan yang bermakna antara usia dengan kejadian karies rampan pada anak TK

\section{SARAN}


1. Bagi Siwa Taman Kanak-Kanak diharapkan untuk mengurangi konsumsi jajanan kariogenik seperti permen, coklat, es krim dan meningkatkan konsumsi buah-buahan yang berserat dan banyak mengandung air seperti jambu, jeruk, semangka, apel, dan pir. Melakukan upaya kebersihan gigi dan mulut yang baik, dengan menyikat gigi sebelum tidur dan berkumur-kumur serta minum air putih setelah mengonsumsi jajanan kariogenik.

2. Orang Tua Siswa Taman KanakKanak diperlukan peran orang tua, terutama dalam mengontrol dan mengawasi jenis jajanan dan frekuensi konsumsi jajanan kariogenik yang dikonsumsi anak.

3. Untuk penelitian selanjutnya, disarankan untuk melakukan penelitian jenis jajanan yang lebih spesifik lagi terhadap kejadian karies rampan menggunakan metode penelitian yang lebih baik lagi, dengan range umur untuk responden lebih diperbesar (3-6 tahun).

\section{KEPUSTAKAAN}

1. SS , Ismu. Karies Gigi pada Anak dengan berbagai faktor Etiologi. Jakarta : EGC; 1992.

2. Ruslawati Y. Diet yang dapat merusak gigi pada anak-anak. Cermin Dunia Kedokteran NO 7. 1991.
3. Soendoro T.. Laporan Hasil Rinset Kesehatan Dasar (RISKESDAS) Nasional 2007. Badan Penelitian dan Pengembangan Kesehatan. Jakarta; 2008.

4. DKK Padang. 2009. Laporan Tahunan Kesehatan Gigi dan Mulut.

5. DKK Padang. 2010. Laporan Tahunan Kesehatan Gigi dan Mulut.

6. Dalimunthe, Taqwa dkk. Pedodonti Dasar. Medan :USU Press; 2009.

7. Mc Donald Ralph E, Avery David R, Dean Jeffrey A. Dentistry For The child and Adolescent. Mosby, 8ed; 2009

8. Kennedy DB. Konservasi Gigi Anak, edisi 3. Jakarta : EGC; 1993.

9. Elianora D. Total Care pada Perawatan Karies Rampan Anak pada Usia 5 tahun dengan Sistem Blok. Majalah Kedokteran Gigi Volume 16; 2009.

10. Jazzalina Aiza Jamil. Hubungan antara kebiasaan mengkonsumsi jajanan dengan pengalaman karies pada gigi susu anak usia 4-6 tahun di TK Medan. Skripsi. Medan, Indonesia : Universitas Sumatra Utara; 2011.

11. Hidayati, Lilik. Hubungan Karakteristik Keluarga dan Kebiasaan Konsumsi Makanan Kariogenik dengan Keparahan Karies Gigi Anak Sekolah Dasar di Kecamatan Cihedeung Tasikmalaya.Tesis. Semarang, Indonesia : Universitas Diponegoro; 2005.

12. Besford J. Mengenal Gigi Anda. In: Budiman JA, Yuwono L editors. Jakarta:Arcan; 1996.

13. Sutadi, Heriadi. Penanggulangan Karies Rampan serta Keluhannya pada Anak. Kedokteran Gigi Universitas Indonesia volume 9; 2002.

14. Roeslan B. Aspek Biokimia Proses terjadinya Karies Gigi. Jurnal Kedokteran Gigi Universitas Indonesia edisi khusus KPPIKG XI; 1997.

15. Winter GB, dkk. Role of the Comforter as a Aetiological Factor in Rampant Caries of Deciduous Dentition. London; 1966.

16. Drinkard Carol, Dilley Dianne CH. Rampant Caries as a Result of a Bizzare Food Habit. Case Report. The American Academy of Pedodontics; 1982.

17. $\mathrm{H} \mathrm{W}, \mathrm{H} \mathrm{H}$, Hendartini Y. Hubungan antara konsumsi karbohidrat dengan tingkat 
keparahan karies gigi pada anak usia prasekolah di kecamatan Depok, Sleman Yogyakarta. Berita Kedokteran Masyarakat; 2002.

18. Nizel AE, Papas AS. Nutrition in Clinical Dentistry. 3rd ed. Philadelphia,London, Toronto: W. B Saunders Co; 1989.

19. Kidd EM. Dasar-dasar karies. In: Sumawinata N, Yuwono L, editors. Dasardasar karies. Jakarta: EGC; 1992.
20. PRL, Meishi. Hubungan Tingkat Konsumsi Makanan Kariogenik dengan Karies Gigi pada Anak Sekolah Dasar Swasta Muhammadiyah 08 Medan Tahun 2011. Skripsi. Medan, Indonesia : Universitas Sumatra Utara; 2012.

21. Tarigan R..Karies Gigi. Jakarta : Hipokrates; 1990. 